\title{
ЛОГІКА МІЖДИСЦИПЛІНАРНОГО ПІДХОДУ ДО СВОЄЧАСНОЇ ДІАГНОСТИКИ ТА ЛІКУВАННЯ КРОВОТЕЧ В АКУШЕРСТВІ ТА ГІНЕКОЛОГІЇ: ПОБУДОВА ЗАДАЧНОЇ ОНТОЛОГІї
}

\author{
О. В. Голяновський, Н. В. Сінєнко, О. М. Вернер \\ Національна медична академія післядипломної освіти імені П. Л. Шупика
}

\begin{abstract}
Розглянуті питання упорядкування знань при рішенні задач діагностики та лікування кровотеч в акушерстві та гінекології, проблеми побудови онтологічних моделей медичних знань при кровотечах. Обґрунтована трансформація сучасних уявлень у цьому напрямку в онтологічну модель. На основі застосування уніфікованих правил та відповідних моделей запропонована уніфікована платформа телемедичного консультування зі зворотним зв'язком.
\end{abstract}

Ключові слова: кровотечі в акушерстві та гінекології, міждисциплінарний підхід, онтологічні моделі знань, телемедичне консультування, тезаурусний кластер, трансфер знань, післядипломна медична освіта.

\section{ЛОГИКА МЕЖДИСЦИПЛИНАРНОГО ПОДХОДА К СВОЕВРЕМЕННОЙ ДИАГНОСТИКЕ И ЛЕЧЕНИЮ КРОВОТЕЧЕНИЙ В АКУШЕРСТВЕ И ГИНЕКОЛОГИИ: ПОСТРОЕНИЕ ЗАДАЧНОЙ ОНТОЛОГИИ}

\author{
О. В. Голяновский, Н. А. Синенко, О. М. Вернер \\ Национальная медицинская академия последипломного образования имени П. Л. Шу- \\ пика
}

\begin{abstract}
Рассмотрены вопросы упорядочения знаний при решении задач диагностики и лечения кровотечений в акушерстве и гинекологии, проблемы построения онтологических моделей медицинских знаний при кровотечениях. Обоснована трансформация современных представлений в этом направлении в онтологическую модель. На основе использования унифицированных правил и соответствующих моделей предложена унифицированная платформа телемедицинского консультирования с обратной связью.
\end{abstract}

Ключевые слова: кровотечения в акушерстве и гинекологии, междисциплинарный подход, онтологические модели знаний, телемедицинское консультирование, тезаурусный кластер, трансфер знаний, последипломное медицинское образование.

\section{THE LOGIC OF AN INTERDISCIPLINARY APPROACH TO EARLY DIAGNOSIS AND TREATMENT OF BLEEDING IN OBSTETRICS AND GYNECOLOGY. BUILDING TASK ONTOLOGY \\ O. V. Golyanovskyy, N. A. Sinienko, O. M. Verner \\ National Medical Academy of Postgraduate Education named P.L.Shupyk}

\begin{abstract}
Resume. The questions of the ordering of knowledge in solving problems of diagnosis and treatment of bleeding in obstetrics and gynecology, the problem of constructing ontological models of medical knowledge for bleeding. There is justified the transformation of modern ideas in the ontological model direction. Through the use of standardized rules and corresponding models proposed unified platform telemedicine consultation feedback.
\end{abstract}

Key words: bleeding in obstetrics and gynecology, inter disciplinary approach, ontological model of knowledge, telemedical consultations, thesaurus cluster, the knowledge transfer, postgraduate medical education.

Вступ. Проблеми прогнозування виникнення та лікування кровотеч в акушерстві та гінекології залишаються на даний час одними 3 найактуальніших.
Так, кровотечі належать до числа найважливіших причин звернень жінок з гінекологічними захворюваннями в останні роки. Близько 65 \% пацієнток ре-

(с) О. В. Голяновський, Н. В. Сінєнко, , О. М. Вернер 
продуктивного віку звертаються до лікарів 3 приводу маткових кровотеч. Від 30 до 50 \% підлітків (залежно від регіону проживання) страждають порушеннями менструального циклу. Спостерігається «омолодження» міоми матки, яка доволі часто є причиною маткової кровотечі.

Акушерські кровотечі також залишаються й однією з основних причин материнської смертності та захворюваності в усіх країнах світу, коливаючись у межах 3-8 \% від загальної кількості пологів. Вони, за даними літератури, є провідною причиною материнської смертності, щорічно у світі від цього ускладнення помирає понад 120 тисяч жінок. Післяпологові кровотечі (I IIIK) відіграють провідну роль серед причин материнської смертності, складаючи в питомій вазі - 17-40 \%, смертність становить 1 на 1000 випадків пологів на рік [6]. У розвинених країнах, зокрема у Великобританії, смертність від ППК становить 1 на 100000 випадків. Частота післяпологових кровотеч в США складає 3,9 \% при пологах через природні родові шляхи і 6,4 \% - при кесаревому розтині (за даними Американського Коледжу акушерства і гінекологіi) [9].

Для ранньої та своєчасної діагностики причин акушерських кровотеч необхідно ретельне клінічне спостереження та виділення груп ризику. Однак, незважаючи на існуючі в світі протоколи і стандарти профілактики, які дозволяють виділити групи ризику розвитку даного ускладнення, рівень материнської смертності від масивних акушерських кровотеч залишається високим. Крім того, для зменшення частоти і наслідків кровотеч необхідно вдосконалювати організацію системи охорони здоров'я, систему надання екстреної медичної допомоги, i, що особливо важливо, - своєчасного використання телемедичних консультацій. Найважливіше значення мають також проблеми впорядкування накопичених знань і передача їх в процесі безперервного професійного розвитку акушерів і гінекологів.

Мета дослідження. Розробити правила упорядкування знань про кровотечі для своєчасної їх діагностики та обгрунтованого лікування в акушерстві та гінекології. Побудова онтологічних моделей медичних знань про кровотечі, що відповідає сучасним уявленням у цьому напряму. На основі обгрунтованих правил та онтологічних моделей створити уніфіковану платформу телемедичного консультування зі зворотним зв'язком.

Матеріал та методи дослідження. В основу дослідження покладений досвід діагностики та лікування 157 жінок з акушерськими кровотечами, що були пов'язані атонією матки. Технологічно ми орієнтувалися на роботи С. В. Денісенко (2014), який створив технологію використання онтологічних моделей для задач діагностики та прогнозування, а також Ф. М. Москаленко (2005), присвячених банку знань iз медичної діагностики, заснованому також на онтології. Згідно з принципами, що оговорені в цих роботах, найактуальнішим завданням є розроблення системи медичної діагностики, заснованої на знаннях експертів, і складної моделі онтології (враховує такі особливості медичних знань як знання про причини захворювань, знання про різні типи причинних зв'язків між ознаками та захворюваннями, знання про вплив подій і анатомо-фізіологічних особливостей на значення ознак при захворюваннях у здорових пацієнтів). Також був використаний розгалужений алгоритм, що оптимізує перетворення бази знань про захворювання в конкретних випадках, у результаті чого можливе суттєве скорочення кількості гіпотез щодо діагнозу.

Отримані результати. Створення онтологічної моделі знань потребує, перш за все, систематизації класифікацій та уніфікації глосарію. Розглядаючи існуючі класифікаційні схеми, нами була використана пропозиція МКХ - 10 перегляду та клінічна класифікація акушерських кровотеч (АК) в пологах та післяпологовому періоді. Термінологічно нами також використовувалися дефініції, що запропоновані ВООЗ.

Серед задач, для яких вважаємо вкрай доцільним застосування онтологічних моделей, є прогнозування можливих кровотеч, використовуючи прогностичні фактори ризику. В цьому випадку, використовуючи комплексну терапію, що включає поєднання інфузійно-трансфузійної терапії, а також хірургічного зупинення кровотечі, можна забезпечити запобігання розвитку атонічної кровотечі після пологів.

Отже, основним методом боротьби з масивними акушерськими кровотечами $є$ їх профілактика, яка залежить від своєчасного виявлення факторів ризику, пов'язаних з формою і ступенем порушень системи гемостазу, а також від розуміння патофізіологічного взаємозв'язку між патогенезом порушень системи гемостазу і виникаючими ускладненнями.

До теперішнього часу не існує і правил оцінки тяжкості стану пацієнток. Визначення, засноване на оцінці гемодинамічних параметрів, не дозволяє повноцінно оцінити тяжкість стану, так як фізіологічна гіперволемія під час вагітності часто дозволяє компенсувати гемодинамічні порушення. Патологічними наслідками геморагічного шоку внаслідок масивної ППК є тканинна гіпоксія, ацидоз, вивільнення проза- 
пальних цитокінів і блискавичний розвиток синдрому системної запальної відповіді, ДВЗ-синдрому, що викликає системні мікросудинні тромбози і гіпоперфузію органів.

Незважаючи на те, що останнім часом намітився певний прогрес у галузі діагностики порушень гемостазу, в арсеналі лікаря відсутні надійні, інформативні, оперативні методи, що дозволяють оцінити валідність, достовірність і значимість відомостей про стан ланок системи гемокоагуляції і фібринолізу та їх функціональної взаємодії.

Відповідно, нами розглянуті прогностичні фактори ризику. Вони згруповані в кластери за принципом «4Т» - «тонус (порушення скоротливої функції матки)», «тканини (затримка тканин в порожнині матки)», «травми (травми пологових шляхів)», «тромбін (порушення коагуляції)». Важливо підкреслити, що кожен 3 кластерів, по суті, являє собою віртуальну задачну онтологічну модель. У кожному з кластерів окремо розглядалися етіологічні та клінічні фактори ризику.

Онтологічна модель кровотеч створювалася нами шляхом логічного аналізу «від верху - до низу» запропонованого в [4]. При цьому намагалися мінімізувати кількість близьких понять, тобто зменшити багатозначність лексики.

Подібний підхід дозволяє суттєво зменшити кількість помилок, що можливі при телемедичному консультуванні жінок 3 кровотечами, за рахунок логічного конструювання комунікаційного спілкування.

Організація інформації в онтології допомагає надалі швидко будувати експертні системи та програми для роботи з даними. Однак, для вирішення багатьох практичних завдань необхідна акумуляція різнобічних знань, що включають не тільки поняттєвий апарат, а й процедурні, фактографічні, евристичні знання. Оскільки отримані знання містяться переважно в текстах, вкрай важливо було встановити певні відповідності між ієрархічними лексичними ресурсами. Іншими словами, базовою словниковою одиницею було не окреме слово, а синонімічний ряд, що об'єднує слова з близьким значенням, по суті, 3 такими що є вузлами відповідної мережі. Таким чином ми створювали тезаурусний кластер.

\section{Література}

1. Палагин А. В. Онтологические методы и средства обработки предметных знаний (монография) / А. В. Палагин, С. Л. Крывый, Н. Г. Петренко. - Луганск : ВНУ им. В. Даля, 2012. -324 c.
Підкреслимо, що з точки зору навчальної інформації для підготовки висококваліфікованих лікарів i провізорів на етапі безперервного професійного розвитку структури онтології можуть бути корисними для ефективного передавання знань. Перш за все, вони дозволяють упорядкувати наявну інформацію. Наприклад, при об'єднанні знань про лікування пацієнтів з кровотечею об'єднуються дані щодо патогенезу, використання ліків, особливостей патологічного процесу тощо. Зрозуміло, що подібний потік інформації без використання впорядкованих баз знань неможливо ефективно застосовувати при підготовці фахівців. Важливо, що детально розроблена онтологія може бути повторно використана в іншій предметній області, а кілька онтологій можуть бути інтегровані в одну. Також для розширення опису необхідної предметної онтології можна повторно використовувати структуру попередньої ітерації.

Важливою є висока ефективність онтологічних моделей в процесах пошуку клінічного прецеденту. Завдяки побудові онтологій вдається створювати досить релевантний до запиту образ, що може дозволити ефективно знайти дані щодо ефективності застосованих раніше підходів. Підкреслимо, що технологія пошуку за допомогою онтологій дозволяє враховувати семантику та контекст запиту, підвищуючи релевантність знаходження аналогічних клінічних випадків.

Це дає можливість по новому конструювати практичні заняття під час навчання в системі післядипломної освіти.

Висновки. 1. Запропоновані основні принципи концепції та структури бази знань з медичної діагностики станів пацієнтів з кровотечами. іії основою є можливість проблемного підключення додаткових онтологій, використовуючи вузлові точки. База знань містить модель онтології предметної галузі, складається 3 трьох частин: модель спостережень, модель знань щодо захворювань, модель історій хвороб пацієнтів.

2. Для подолання проблем, що пов'язані з поганою структурованістю медичної інформації, виявлення основних елементів діагностичного та лікувального процесу пропонується технологія експертної міждисциплінарної оцінки.

2. Москаленко Ф. М. Банк знаний по медицинской диагностике, основанный на нетривиальной онтологии / Ф. М. Москаленко // Научная сессия МИФИ-2008. Сборник научных трудов. В 15 томах. Интеллектуальные системы и технологии. - М. : МИФИ, 2008. - Т. 10. - С. 87-88. 


\section{МЕДИЧНА ІНФОРМАТИКА}

\section{TA IHЖЕНЕРІЯ}

3. Москаленко Ф. М. Задача медицинской диагностики и алгоритм её решения, допускающий распараллеливание / Ф. М. Москаленко // Информатика и системы управления. - 2005. - № 2 (10). - С. 52-63.

4. Денисенко С. В. Інформаційні технології в стратегії збереження та відновлення репродукції людини : автореферат дисертації на здобуття наукового ступеня доктора медичних наук / С. В. Денисенко, 2010. - 43 с.

5. Голяновський О. В. Кровотечі в практиці акушера-гінеколога : навчальний посібник / О. В. Голяновський, С. С. Леуш, Т. Г. Романенко. - Київ, 2013. - 240 с.
6. Серов В. Н. Неотложные состояния в акушерстве / В. Н. Серов, Г. Т. Сухих, Н. И. Баранов. - М., 2011. - 784 с. 7. Тромбогеморрагические осложнения в акушерскогинекологической практике: Руководство для врачей / Под ред. А. Д. Макацария. М. 2011; 1056 с.

8. El-Rafaey H., Rodeck C. Post-partum hemorrhage: definitions, medical and surgical management. A time for change. Br. Med. Bull. 2003; 67: 205-17.

9. James A.H., McLintock C., Lockhart E. Postpartum hemorrhage: when uterotonics and sutures fail. Am. J. Hematol. 2012; 87 (1): 16. 